\title{
One patient, one bone, and two different tumoral lesions
}

\author{
Bir hasta, bir kemik ve iki ayrı tümoral lezyon
}

\author{
O. Şahap Atik, MD, ${ }^{1}$ Tacettin Ayanoğlu, MD, ${ }^{1}$ Hakan Atalar, MD, ${ }^{1}$ Mehmet Yörübulut, MD. ${ }^{2}$ \\ 'Department of Orthopedics and Traumatology, Medical Faculty of Gazi University, Ankara, Turkey \\ ${ }^{2}$ Department of Radiology, Ankara Acıbadem Hospital, Ankara, Turkey
}

\begin{abstract}
In this article, we report a 67-year-old female patient who has two different tumoral lesions located in left humerus with clinical and radiological findings. Previously, the patient was diagnosed as impingement syndrome in shoulder, but, tumoral lesions were detected on the radiograms incidentally during evaluation.

Keywords: Bone; intraosseous lipoma; simple bone cyst; tumoral lesions.
\end{abstract}

There are several tumors and tumorlike conditions with variable biological behavior that may involve the bones. ${ }^{[1]}$ However, histopathologically, some of these lesions are not really malignant. They are usually seen in childhood, but also rarely in adults. They mostly present an asymptomatic course and are diagnosed with radiographs taken for any other reason. Their detection is important because of their risk to cause pathological fractures. Cyst aspiration, steroid injections, curettage, and grafting are applied to the patients with high risk of pathological fracture.

In this article, we described a patient who has two different tumoral lesions located in left humerus with clinical and radiological findings. Previously, the patient was diagnosed as impingement syndrome, but, tumoral lesions were detected on the radiograms incidentally during evaluation. . $^{[2,3]}$

\section{CASE REPORT}

A 67-year-old female patient referred to another clinic with right shoulder pain. Previously, she was diagnosed as impingement syndrome; however,
$\ddot{O Z Z}$

$\mathrm{Bu}$ yazıda, klinik ve radyolojik bulgularla sol humerusunda iki ayrı tümoral lezyon olan 67 yaşında bir kadın hasta sunuldu. Hastaya daha önce omuzda sıkışma sendromu tanısı konuldu, fakat değerlendirme sırasında röntgenlerde tesadüfen tümoral lezyonlar tespit edildi.

Anahtar sözcükler: Kemik; intraosseöz lipom; basit kemik kisti; tümoral lezyonlar.

left humerus lesions were detected on the X-ray views incidentally during evaluation. There were no symptoms such as pain, numbness, swelling, or redness at left upper extremity. Pain elicited at diaphyseal humerus when applying pressure with finger, but did not affect patient's daily life or caused her to wake up at night. Patient had no history of trauma. A written informed consent was obtained from the patient.

Bone scintigraphy was performed. There was no abnormal uptake in the proximal left humerus and it was more expanded compared to the other humerus. The scintigraphy was reported as compatible with simple cyst. Subsequently, left upper extremity tomography was taken. A smooth, limited, thin mass with sclerotic edges and approximately $2 \times 3 \mathrm{~cm}$ in size was detected in the humeral metaphyseal level and considered as "simple bone cyst". In the humeral diaphyseal level; a heterogeneous mass was detected approximately $4 \times 2 \mathrm{~cm}$ in size with lobular contour, containing areas of fat density, and causing slight expansion in the bone, which was reported as "intraosseous lipoma". Magnetic resonance imaging

\footnotetext{
- Received: October 18, 2015 Accepted: November 13, 2015

- Correspondence: O. Şahap Atik, MD. Gazi Üniversitesi Tıp Fakültesi Ortopedi ve Travmatoloji Anabilim Dalı, 06500 Beşevler, Ankara, Turkey. Tel: +90 312 - 2025528 Fax: +90 312 - 2129008 e-mail: satikmd@gmail.com
} 


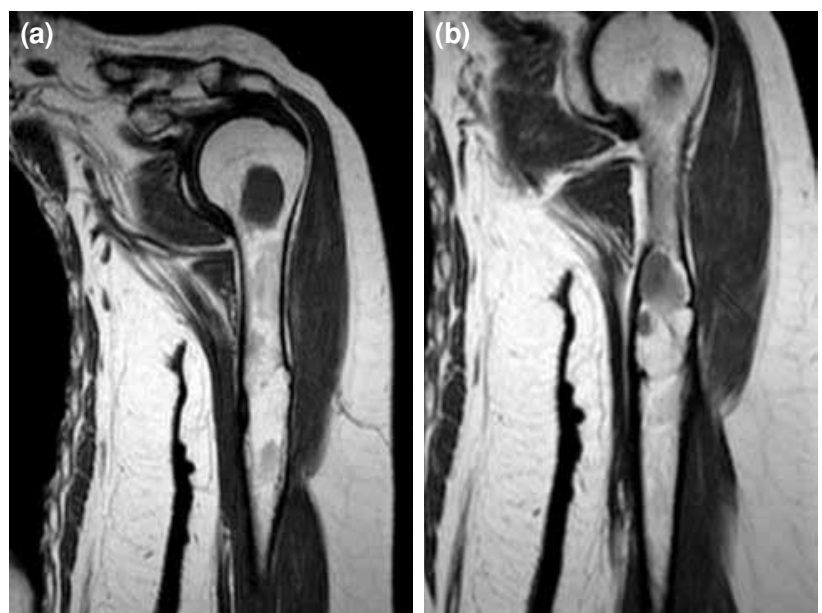

Figure 1. (a) Coronal $T_{1} A$ magnetic resonance image shows a well limited cystic lesion in proximal humeral metaphysis which does not contain calcification or solid component. (b) Coronal $\mathrm{T}_{1} \mathrm{~A}$ magnetic resonance image shows a lesion in humeral shaft that contains fatty and cystic components and causes cortical expansion.

was consistent with simple bone cyst and intraosseous lipoma (Figures 1, 2).

Considering the risk of fracture due to the two lesions, prophylactic surgical treatment was recommended. However, the patient refused surgical treatment. Then, lifestyle changes were described to reduce the risk of fracture development and regular follow-up was recommended.

\section{DISCUSSION}

While multiple lesions in a bone are generally considered as simple bone cysts, aneurysmal bone cysts, or fibrous dysplasias during adolescence, they are primarily regarded as metastases, multiple myelomas, or osteomyelitis in adulthood.

Simple bone cysts are benign lytic bone lesions, usually observed in children and adolescents. They are cystic, fluid-filled lesions, which may be unicameral or partially separated. Unicameral bone cysts may involve all bones, but particularly the long bone metaphysis, and the proximal humerus and proximal femur. ${ }^{[4]}$ The cortex may become fragile. Cyst aspiration, steroid injections, curettage, and grafting are applied to the patients with high risk of pathological fracture.

In the elderly, the content of the cyst generally changes to fibroadipose tissue. Classically, fibrous dysplasia lesions are intramedullary, expansile, and well defined. Although endosteal scalloping may be present, a smooth cortical contour is always maintained.

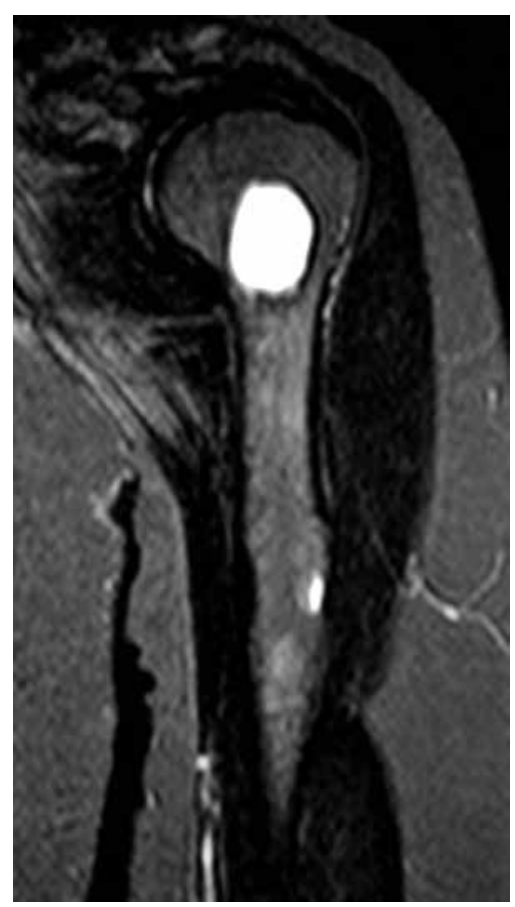

Figure 2. Coronal fat saturation image after intravenous injection of contrast material. An intramedullary cystic lesion is observed with thin rim of contrast enhancement in proximal humeral metaphysis. Diaphyseal lesion has fat suppression and no contrast enhancement.

Lesions show varying degrees of hazy density with a ground-glass quality, although some may appear almost completely radiolucent or sclerotic. ${ }^{[5]}$

Although there is too much fatty tissue in bone marrow, intraosseous lipomas are rare. Intraosseous lipoma is seen more often in facial bones, ribs, ulna, tibia, fibula, and calcaneus. Radiographically, the lesions appear osteolytic and well delineated. Curettage and packing with autogenous bone grafts are treatment options for this rare tumor. ${ }^{[6]}$

In the literature, various cases were reported regarding simple bone cysts in different bones of the same patient. ${ }^{[7]}$ However, we detected only one paper on two different lesions in the humerus, involving a 10-year-old girl with fibrous dysplasia associated with aneurysmal bone cyst, both confirmed by histopathology. Authors have emphasized that this condition further increases the risk of fracture development by weakening the bone. ${ }^{[8]}$

\section{Declaration of conflicting interests}

The authors declared no conflicts of interest with respect to the authorship and/or publication of this article. 


\section{Funding}

The authors received no financial support for the research and/or authorship of this article.

\section{REFERENCES}

1. Surov A, Weber MA. Malignant and benign lesions of the skeletal musculature. Semin Ultrasound CT MR 2014;35:290-307.

2. Beytemür O, Tetikkurt ÜS, Albay C, Adanır O, Güleç MA. Acute myeloid leukemia diagnosed with soft tissue mass in the right thigh. [Article in Turkish] Eklem Hastalik Cerrahisi 2015;26:56-9.

3. Uemura T, Yagi H, Okada M, Yokoi T, Shintani K, Nakamura H. Elbow septic arthritis associated with pediatric acute leukemia: a case report and literature review. Eklem
Hastalik Cerrahisi 2015;26:171-4

4. Jee WH, Choi KH, Choe BY, Park JM, Shinn KS. Fibrous dysplasia: MR imaging characteristics with radiopathologic correlation. AJR Am J Roentgenol 1996;167:1523-7.

5. Jee WH, Choi KH, Choe BY, Park JM, Shinn KS. Fibrous dysplasia: MR imaging characteristics with radiopathologic correlation. AJR Am J Roentgenol 1996;167:1523-7.

6. Aumar DK, Dadjo YB, Chagar B. Intraosseous lipoma of the calcaneus: report of a case and review of the literature. J Foot Ankle Surg 2013;52:360-3.

7. Sadler AH, Rosenhain F. Occurrence of two unicameral bone cysts in the same patient. J Bone Joint Surg [Am] 1964;46:1557-60.

8. Nguyen BD, Lugo-Olivieri CH, McCarthy EF, Frassica FJ, Ma LD, Zerhouni EA. Fibrous dysplasia with secondary aneurysmal bone cyst. Skeletal Radiol 1996;25:88-91. 